\title{
Detection of Salmonella typhimurium ATCC 14028 in Powder Prepared Traditional Medicines Using Real-Time PCR
}

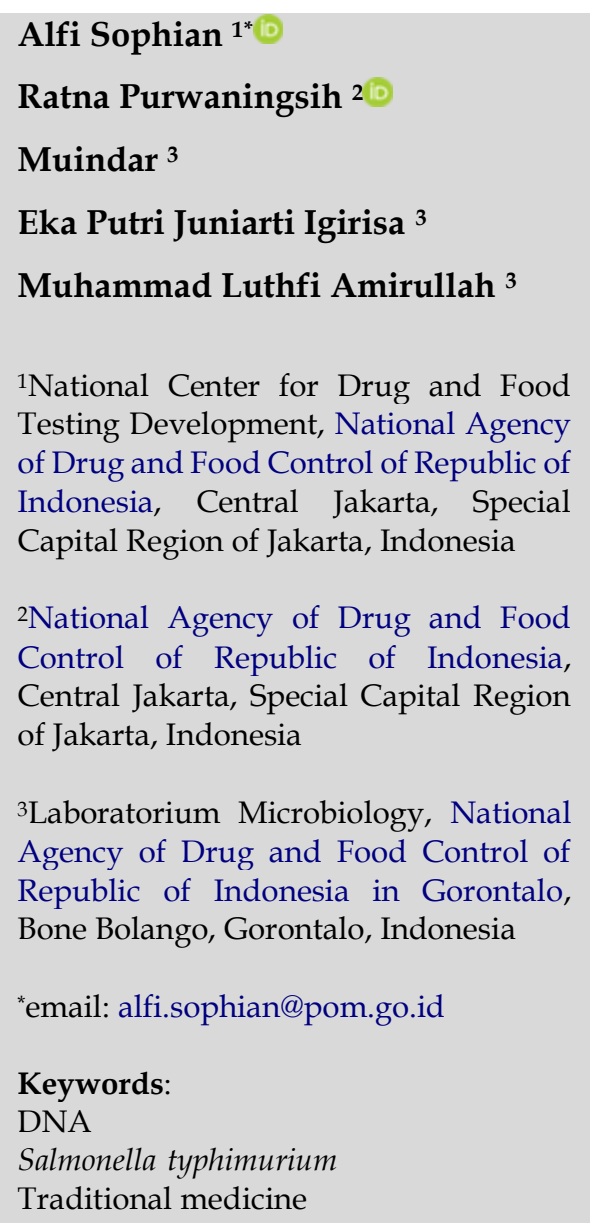

\begin{abstract}
The detection of Salmonella typhimurium ATCC 14028 using real-time PCR on powdered traditional medicinal products was carried out in the microbiology and molecular biology testing laboratory of the Food and Drug Administration in Gorontalo. This research aims to provide a reference for alternative testing methods in testing the products of traditional powder preparations on the market. The sample consisted of 10 traditional powder preparations spiked with positive control of S. typhimurium ATCC 14028 phase 2. The method used in the study was real-time PCR analysis using the SYBR $®$ Green method, while DNA isolation using the direct PCR method. Data analysis was performed by analyzing the sample's melting temperature (Tm) curve and comparing it with positive control. The results showed that $S$. typhimurium ATCC 14028 was detected in samples at an average Tm value of $84.18^{\circ} \mathrm{C}$, with ranges of $84.0-84.5^{\circ} \mathrm{C}$. For positive control, the Tm value was at $85.2^{\circ} \mathrm{C}$, while for the negative control, the Tm value was not detected. Based on these data, it can be concluded that $S$. typhimurium ATCC 14028 in traditional medicine products powder preparations can be detected using real-time PCR.
\end{abstract}

(c) 2021 Alfi Sophian, Ratna Purwaningsih, Muindar, Eka Putri Juniarti Igirisa, Muhammad Luthfi Amirullah. Published by Institute for Research and Community Services Universitas Muhammadiyah Palangkaraya. This is an Open Access article under the CC-BY-SA License (http://creativecommons.org/licenses/by-sa/4.0/). DOI:

https:// doi.org/10.33084/ bjop.v4i3.1838

Received: November 23rd, 2020

Accepted: June 7th, 2021

Published: August 30th, 2021

\section{INTRODUCTION}

Traditional medicines are ingredients in the form of the plant, animal, mineral substances, galenic preparations, or mixtures of these ingredients, which have been used for treatment from generation to generation and can be applied following the prevailing norms in society ${ }^{1,2}$. Traditional medicinal preparations consist of various types, including powder, instant powder, pills, caplets, capsules, and other simple forms. The simple manufacturing process sometimes raises the possibility of contamination by pathogenic bacteria in these traditional medicinal preparations ${ }^{3,4}$.

So far, the method of detecting pathogenic bacteria in traditional medicinal products is still using conventional test method guidelines using selective media. However, the development of science and technology has led to several other alternatives in detecting pathogenic bacteria, one of which is using molecular techniques, Molecular analysis to identify pathogenic bacteria using real-time has advantages when compared to 
conventional methods? The average time required to identify pathogenic bacteria by molecular techniques is faster when compared to conventional methods8.

Regarding the quality requirements of traditional medicines, contaminants from pathogenic bacteria, including Salmonella, Shigella, and Clostridium, should not be found 9 . Members of the genus Salmonella can cause fever and digestive tract diseases, such as $S$. typhimurium ${ }^{10}$. Among several biomolecular techniques for Salmonella detection, polymerase chain reaction (PCR) is the most frequently used. Real-time PCR analysis has better sensitivity in detecting the DNA of Salmonella ${ }^{11}$.

One of the traditional medicines that are often found is in the form of powder preparations. Traditional medicine powder preparations are homogeneous granules with an appropriate, acceptable degree, made from simplicia or a mixture with extracts brewed with hot water ${ }^{12}$. These preparation forms can contain microbial contamination such as S. typhimurium, especially if processed and stored not cleanly and hygienically ${ }^{3}$. Therefore, this research aims to provide an alternative testing method for $S$. typhimurium contamination in traditional powder preparations on the market. The novelty aspect discussed in this study is to provide a source of reference information in the test for detecting pathogenic bacteria in traditional powdered products using real-time PCR. This research is a follow-up study because the data obtained will be used to evaluate several different types of samples so that the effectiveness of the testing methods and techniques used on the various types of samples used can be evaluated.

\section{MATERIALS AND METHODS}

\section{Materials}

The materials used in this study were samples of traditional medicine powder, tryptic soy broth (TSB) and agar (TSA) enrichment media, xylose lysine deoxycholate (XLD) and brilliant green agar (BGA) selective media, and a PCR kit with QuantiNova SYBR $\AA$ Green (Qiagen).

\section{Methods}

\section{Sample criteria and sampling period}

The main criteria for the sample used in this study was a traditional medicine powder consisting of several traditional medicines for shooting pain or "pegal linu" and herbal medicine for women's health. Sampling was carried out at markets and pharmacies in Gorontalo City from October to December 2020.

\section{Sample preparation}

The sample consisted of 10 types of traditional medicinal powder preparations spiked with positive control $S$. Typhimurium ATCC 14028 phase 2.

\section{Isolation on selective media}

A total of $10 \mathrm{~g}$ of sample was weighed and then added 90 $\mathrm{mL}$ of TSB and incubated at $35-37^{\circ} \mathrm{C}$ for $18-24$ hours. One ose of each incubated sample was then taken and streaked on BGA and XLD selective media, then incubated at $35-37^{\circ} \mathrm{C}$ for $18-24$ hours. The observations of colonies growing on selective media were then recorded.

DNA isolation

The results of isolation from selective media are then enriched on media so that it is tilted. The enrichment result was then diluted in physiological $\mathrm{NaCl}$ to obtain turbidity equivalent to the McFarland standard number 1. This equalization result was then used as a DNA template ${ }^{13}$.

\section{Real-time PCR analysis}

Melt curve analysis was carried out using real-time PCR (QIAGEN 5-plex) with the two-step cycling method: denaturation $95^{\circ} \mathrm{C}$ for 45 seconds and annealing/extension $60^{\circ} \mathrm{C}$ for 45 seconds. The primers used to detect $S$. typhimurium were using invA forward 
primers (5'-ATC AGT ACC AGT CGT CTT ATC TTG AT-3'), reverse (5'-TCT GTT TAC CGG GCA TAC CAT$\left.3^{\prime}\right)$.

\section{Reaction setup}

The total volume of the master mix was $10 \mu \mathrm{L}$, consisting of $5 \mu \mathrm{L}$ SYBR ${ }^{\circledR}$ Green master mix, $1 \mu \mathrm{L}$ forward primer, $1 \mu \mathrm{L}$ reverse primer, $1 \mu \mathrm{L}$ water-free RNase, and $2 \mu \mathrm{L}$ template DNA ${ }^{14}$.

\section{Positive control}

The positive control used was S. typhimurium ATCC 14028 phase 2, enriched and scratched by the media to make it tilted. The enrichment result was then diluted in physiological $\mathrm{NaCl}$ to obtain turbidity equivalent to the McFarland standard number $1^{14}$.

\section{Negative control}

The negative control used was no template control (NTC), a master mix combined with primer and nucleic acid-free water. The total negative control volume was 10 $\mu \mathrm{L}$, consisting of $1 \mu \mathrm{L}$ forward primer, $1 \mu \mathrm{L}$ reverse primer, $3 \mu \mathrm{L}$ RNase free water, with the rest was SYBR ${ }^{\circledR}$ Green master mix ${ }^{14}$.

\section{Specificity}

Specificity was carried out by replacing the target bacterial DNA with other bacterial DNA to see whether the non-target DNA was amplified or not. In addition, another function of the specificity test was to examine whether the primer used was specific or not.

\section{Limit of detection}

The limit of detection (LOD) was carried out by replacing the sample DNA template with a positive control diluted 10 times. This step aims to determine the sensitivity of the tool in detecting low concentrations of target DNA.

\section{Data analysis}

Data analysis was carried out by seeing the amplification results of the melting temperature $(\mathrm{Tm})$ value, the melting point at the temperature at which the melt occurred, and comparing the melting point for the positive control ${ }^{14}$.

\section{RESULTS AND DISCUSSION}

Isolation on selective media

The isolation process on selective media began with enrichment on TSB media. In this medium, the target bacteria could not be distinguished from other bacteria that could have grown. The general characteristic was only a change in the color of the enrichment medium from clear brownish-yellow to brownish-yellow cloudy ${ }^{15}$. The enrichment stage was carried out to prevent quantifying diseased cells that conventional methods could not be grown/ counted $^{16}$.

Isolation on selective media was using BGA and XLD, the specific media for isolating Salmonella pathogenic bacteria. The profile of Salmonella on XLD was a colony that is round in shape. In BGA, the colony was white to translucent, whereas, in XLD, it could be colorless, very bright, slightly shiny, and transparent (medium color) with a black center, surrounded by a pink area and a yellow border, or a pink to reddish color, with a black or colorless buffer core ${ }^{17,18}$.

Brilliant green agar comprises peptone, tryptone, yeast extract, lactose, sucrose, sodium chloride, phenol red, brilliant green, and agar. Each of the constituent components of the BGA has its respective functions, including as a source of nutrition for amino acid or polypeptide raw materials, maintaining the osmotic balance of the media, sources of carbohydrates that will be needed in the fermentation process, as well as an acidbase indicator. While in XLD media, Salmonella has a translucent round shape with a black spot in the middle. The color change is caused by the fermentation of glucose by Salmonella into organic acids such as lactic, acetic, and formic acids, resulting in a decrease in $\mathrm{pH}^{19}$. Xylose lysine deoxycholate is a non-autoclave medium whose 
components will be damaged if harvested at temperatures above $100^{\circ} \mathrm{C}$. Xylose carbohydrates in XLD play a role in the fermentation process to condition the $\mathrm{pH}$ of the media to become acidic, thereby increasing the $\mathrm{pH}$ to become alkaline. Meanwhile, decarboxylate enzymes produce amines or diamines and carbon dioxide by breaking down amino acid groups. Xylose lysine deoxycholate media is a selective medium for $S$. typhimurium because it has sodium deoxycholate, an inhibitor for Gram-positive bacteria ${ }^{18}$.

\section{Real-time PCR analysis}

Real-time PCR analysis was performed using a qualitative test method using $\mathrm{SYBR} 囚$ Green, and the results were presented in Table I. The data were obtained from 10 samples which were 10 types of traditional medicine with the powder preparation form. The Tm value from real-time PCR analysis was $84.0-84.5^{\circ} \mathrm{C}$, with an average of $84.18^{\circ} \mathrm{C}$. This value is not much different from the positive control at the Tm value of $85.2^{\circ} \mathrm{C}$. This difference could be caused by several things, including the concentration of the template DNA used was not the same. This difference in concentration occurred because the template DNA was not isolated using conventional isolation techniques but instead used the direct PCR method $^{20}$.

Table I. Real-time PCR data analysis

\begin{tabular}{cccccc}
\hline \multirow{5}{*}{ Samples } & \multicolumn{5}{c}{ Treatment } \\
\cline { 2 - 5 } & $\begin{array}{c}\text { Tm Value } \\
\left({ }^{\circ} \mathrm{C}\right)\end{array}$ & $\begin{array}{c}\text { Negative } \\
\text { Control }\end{array}$ & Specificity & LOD & $\begin{array}{c}\text { Positive } \\
\text { Control }\end{array}$ \\
\hline 1 & 84.0 & - & - & 85.0 & 85.2 \\
2 & 84.5 & & & & \\
3 & 84.3 & & & & \\
4 & 84.3 & & & & \\
5 & 84.0 & & & & \\
6 & 84.0 & & & & \\
7 & 84.0 & & & & \\
8 & 84.2 & & & & \\
9 & 84.0 & & & & \\
10 & 84.5 & & & & \\
\hline Average & 84.18 & - & - & 85.0 & 85.2 \\
\hline
\end{tabular}

The results of real-time PCR amplification using the qualitative analysis method SYBR® Green were shown in Figure 1. It could be seen that the positive control shown by the red line indicates an amplification at the $\operatorname{Tm} 85.2^{\circ} \mathrm{C}$, while for the negative control shown with the black line, there was no amplification. The samples shown in green lines indicate an amplification similar to the positive control; this indicates that $S$. typhimurium was detected from the samples.

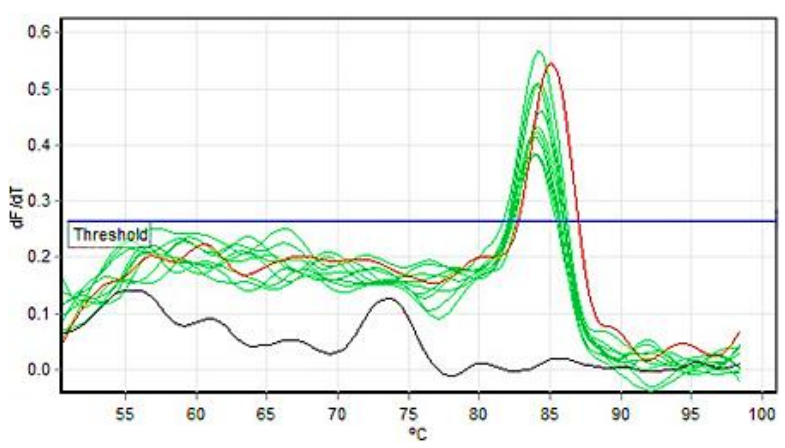

Figure 1. Melt curve analysis for Tm. Green: samples; Red: positive control; Black: negative control

In Figure 1, melt curve analysis shows that the peak of the curve point varies slightly. This variation is due to the composition and size of the nucleotides ${ }^{21}$. In SYBR® Green analysis, a fluorescent signal will emit when the DNA bands separate during the annealing stage. A single peak detected in the melting process indicates the specific level of the detected band. If there is a band difference in the single peak in the melt curve analysis, it can predict the presence of mutations in the detected species $^{22}$.

Molecular testing techniques have their challenges, in which DNA extraction techniques such as physical, chemical, or biological characteristics of the sample to be used will also affect the test's success ${ }^{23}$. Compared with conventional techniques, molecular testing techniques have advantages in several ways, including the relatively faster testing time obtained. Species identification using real-time PCR is a fast and reliable alternative method in developing the molecular world ${ }^{24}$. At least two real-time PCR methods are often used in analyzing species DNA: the TaqMan® and SYBR® Green methods ${ }^{25}$. 


\section{CONCLUSION}

The detection method of S. typhimurium in powder preparations of traditional medicinal products using realtime PCR with the SYBR® Green method can be used, as indicated by the results of all samples tested showing noticeable results.

\section{ACKNOWLEDGMENT}

The author would like to thank the Head of the National Agency of Drug and Food Control of the Republic of Indonesia for the laboratory support.

\section{AUTHORS' CONTRIBUTION}

Alfi Sophian: conceptualization, data curation, data analysis, writing-original draft \& editing. Ratna Purwaningsih: writing-review \& editing. Muindar: writing-review \& editing. Eka Putri Juniarti Igirisa: writing-review \& editing. Muhammad Luthfi Amirullah: writing-review \& editing.

\section{DATA AVAILABILITY}

None.

\section{CONFLICT OF INTEREST}

The authors declare no conflict of interest.

\section{REFERENCES}

1. Yuan $H, M a Q$, Ye L, Piao G. The Traditional Medicine and Modern Medicine from Natural Products. Molecules. 2016;21(5):559. doi:10.3390/molecules21050559

2. Sidoretno WM, Rz IO. Edukasi Bahaya Bahan Kimia Obat Yang Terdapat Didalam Obat Tradisional. Jurnal Pengabdian Masyarakat Multidisiplin. 2018;1(2):36-42. doi:10.36341/jpm.v1i2.453

3. Abba D, Inabo HI, Yakubu SE, Olonitola OS. Contamination of herbal medicinal products marketed in Kaduna metropolis with selected pathogenic bacteria. Afr J Tradit Complement Altern Med. 2008;6(1):70-7. doi:10.4314/ajtcam.v6i1.57076

4. Kumadoh D, Ofori-Kwakye K. Dosage Forms of Herbal Medicinal Products and Their Stability Considerations-an Overview. J Crit Rev. 2017;4(4):1-8. doi:10.22159/jcr.2017v4i4.16077

5. Franco-Duarte R, Černáková L, Kadam S, Kaushik KS, Salehi B, Bevilacqua A, et al. Advances in Chemical and Biological Methods to Identify Microorganisms-From Past to Present. Microoganisms. 2019;7(5):130. doi:10.3390/microorganisms7050130

6. Law JWF, Ab Mutalib NS, Chan KG, Lee LH. Rapid methods for the detection of foodborne bacterial pathogens: principles, applications, advantages and limitations. Front Microbiol. 2015;5:770. doi:10.3389/fmicb.2014.00770

7. Maurer FP, Christner M, Hentschke M, Rohde $\mathrm{H}$. Advances in Rapid Identification and Susceptibility Testing of Bacteria in the Clinical Microbiology Laboratory: Implications for Patient Care and Antimicrobial Stewardship Programs. Infect Dis Rep. 2017;9(1):6839. doi:10.4081/idr.2017.6839

8. Priyanka B, Patil RK, Dwarakanath S. A review on detection methods used for foodborne pathogens. Indian J Med Res. 2016;144(3):327-38. doi:10.4103/0971-5916.198677

9. Bintsis T. Foodborne pathogens. AIMS Microbiol. 2017;3(3):529-63. doi:10.3934/microbiol.2017.3.529

10. Jajere SM. A review of Salmonella enterica with particular focus on the pathogenicity and virulence factors, host specificity and antimicrobial resistance including multidrug resistance. Vet World. 2019;12(4):504-21. doi:10.14202/vetworld.2019.504521

11. Kasturi KN, Drgon T. Real-Time PCR Method for Detection of Salmonella spp. in Environmental Samples. Appl Environ Microbiol. 2017;83(14):e00644-17. doi:10.1128/AEM.00644-17

12. Ekor M. The growing use of herbal medicines: issues relating to adverse reactions and challenges in monitoring safety. Front Pharmacol. 2014;4:177. doi:10.3389/fphar.2013.00177

13. Sophian A, Purwaningsih R, Igirisa EPJ, Amirullah MA, Lukita BL, Fitri RA. Short Communication: 
Detection of Salmonella typhimurium ATCC 14028 and Listeria monocytogenes ATCC 7644 in processed meat products using Real-Time PCR Multiplex Method. Asian J Nat Prod Biochem. 2021;19(1):17-20. doi:10.13057/biofar/f190103

14. Sophian A, Purwaningsih R, Lukita BL, Ningsih EC. Detection of Salmonella typhimurium ATCC 14028 in supplement health product liquid preparation using Real-Time PCR (qPCR). Asian J Nat Prod Biochem.

2020;18(2):61-65.

doi:10.13057/biofar/f180202

15. Kang DH, Fung DY. Application of thin agar layer method for recovery of injured Salmonella typhimurium. Int J Food Microbiol. 2000;54(1-2):12732. doi:10.1016/s0168-1605(99)00174-9

16. Lagier JC, Edouard S, Pagnier I, Mediannikov O, Drancourt M, Raoult D. Current and Past Strategies for Bacterial Culture in Clinical Microbiology. Clin Microbiol Rev. 2015;28(1):208-36. doi:10.1128/CMR.00110-14

17. Bonnet M, Lagier JC, Raoult D, Khelaifia S. Bacterial culture through selective and non-selective conditions: the evolution of culture media in clinical microbiology. New Microbes New Infect. 2020;34:100622. doi:10.1016/j.nmni.2019.100622

18. Park SH, Ryu S, Kang DH. Development of an Improved Selective and Differential Medium for Isolation of Salmonella spp. J Clin Microbiol. 2012;50(10):3222-6. doi:10.1128/JCM.01228-12

19. El Shamy HA, Bakr WM, Gomaa NF, Barheem OH. Evaluation of two enrichment broths, three plating media and ELISA technique for the isolation of salmonella from dairy products. J Egypt Public Health Assoc. 2008;83(1-2):133-45.

20. Gupta N. DNA Extraction and Polymerase Chain Reaction. J Cytol. 2019;36(2):116-7. doi:10.4103/JOC.JOC_110_18

21. Shinozuka H, Forster JW. Use of the melting curve assay as a means for high-throughput quantification of Illumina sequencing libraries. PeerJ. 2016;4:e2281. doi:10.7717/peerj.2281

22. Zhang H, Gaňová M, Yan ZQ Chang H, Neužil P. PCR Multiplexing Based on a Single Fluorescent Channel Using Dynamic Melting Curve Analysis. ACS Omega. 2020;5(46):30267-73. doi:10.1021/acsomega.0c04766
23. Ali N, Rampazzo RdCP, Costa ADT, Krieger MA. Current Nucleic Acid Extraction Methods and Their Implications to Point-of-Care Diagnostics. Biomed Res Int. 2017;2017:9306564. doi:10.1155/2017/9306564

24. Kralik P, Ricchi M. A Basic Guide to Real Time PCR in Microbial Diagnostics: Definitions, Parameters, and Everything. Front Microbiol. 2017;8:108. doi:10.3389/fmicb.2017.00108

25. Gašparič MB, Cankar K, Žel J, Gruden K. Comparison of different real-time PCR chemistries and their suitability for detection and quantification of genetically modified organisms. BMC Biotechnol. 2008;8:26. doi:10.1186/1472-6750-8-26 